\title{
Shifting selves: the emergence of new identities in South African schools
}

\author{
Saloshna Vandeyar \\ University of Pretoria
}

\begin{abstract}
This is an exploratory study on the nature and extent of racial integration in South African schools in the post-apartheid period. While there is vigilant media attention to occasional, dramatic incidents of racial conflict in white schools, there is very little research on the ways in which student identities are framed, challenged, asserted and negotiated within the dominant institutional cultures of former white schools. The research findings suggest that student identities are shaped and framed within stable institutional cultures that remain impervious to change despite the changing demographics of the student body; but that even under these conditions student identities are constantly being questioned and recast as black and white students begin to engage each other in the daily routines of institutional life.
\end{abstract}

Keywords: Curriculum; Educational policy; International education; Educational administration; Identity; Race

\section{Introduction}

In South Africa, "race remains the primary point of reference" (Soudien, 1994, p. 56; Soudien et al., 2004). Under apartheid, race interpretations not only pursued the path of the discredited theory of fundamental nature, but also in doing so, played a key role in human rights abuses. In an attempt to protect and rationalise economic and administrative privilege and power of the minority white population, four essentialised racial classifications were legislated: White, African, Coloured and Indian ${ }^{1}$ (Moodley and Adam, 2004). The latter three have been further homogenised through the common representation of blackness, and consequently, in post-apartheid discourse, the black experience (Potgieter, 2002).

To ensure continued supremacy, whiteness was fabricated and presented as morally, intellectually and biologically superior contrasted to blackness as subaltern. In accordance with the prevailing mentality, identities were presented as rigid and fixed. Education reflected this segregated and inequitable environment, with every aspect of schooling regulated according to race (Carrim, 1998; Sayed, 2001).

The need for rectification and parity in all aspects of education was thus a necessary imperative in a new, democratic education system (Sayed, 2001). Since 1994, various policies have been developed and legislation enacted to encourage the process of desegregation [read: integration] in the schooling system of South Africa. The South African Schools Act (Act no. 37 of 1996) catalysed by the Bill of Rights and the South 
African Constitution, formalised the desegregation of schools in South Africa, and created the opportunity for students from diverse cultural backgrounds to attend schools of their choice. It was hoped that in creating this opportunity, students would become integrated into the whole school environment and the seed of a new society will be sown.

Although the above policies set the stage for desegregation to unfold at schools, by establishing the physical proximity of members of different groups in the same school, it did not go further to interrogate the quality of contact; not only in the personal attitudes of students and teachers but also in the institutional arrangements, policies and ethos of the school (Sayed, 2001, p. 254). As a result, 12 years down the line schools in South Africa are "still grappling with the apartheid legacy of separate and unequal schooling" (Moletsane et al., 2004, p. 61). Instead of becoming models of societal integration (Jansen, 2004), schools have continued to reflect the hegemonic dominance of whiteness that characterised pre-apartheid schooling and as a result racism has continued unabated (Vally and Dalamba, 1999). Studies have indicated that popular culture has further entrenched the polarities of whiteness and blackness. In an attempt to regain lost power and privilege in a post-apartheid South Africa, research showed that white students reformulated their personal and collective identities through an illusory link to Europe. Eurocentric popular culture was seen to be emblematic of white privilege and protection (Dolby, 2000). Black popular culture became a yardstick in interpretations of whiteness as through the negation of blackness, white students were able to reconstruct a "global white" identity unrelated to the nation-state (Dolby, 2000).

Earlier studies in this field most notably that of (Dolby, 2000), (Dolby, 2001) and (Dolby, 2002) and Vally and Dalamba (1999) explores how South African youth make meaning of the idea of race. The Vally and Dalamba (1999) report uncovered overt forms of racial practices and youth identity that centred on the issue of "them" and "us". Dolby's studies have shown that in the new context of globalisation, fashion, style, and ultimately "taste", compete with "ancestry" and "geography" as pivotal variables in the elaboration of youth identities.

There is however, very little research on the ways in which student identities are framed, challenged, asserted and negotiated within the dominant institutional cultures of former white schools. Accordingly, this study asks: What indeed is the nature of student relationships and interactions within the school, and to what extent has the school organised itself to provide positive relations among black and white students?

The following research questions guided this study: (1) To what extent has the ethos of these schools been transformed towards integration in the truest sense and how do students perceive this in practice? (2) Are new forms of self-identity beginning to emerge?

The argument is presented as follows. I begin by outlining from current research a conceptual framework on the reinvention and renegotiation of the construct "race". I then describe the sample and context and the research methodology that was implemented. The development of themes that emerged from interviews is subsequently presented. I 
conclude with an analysis and discussion of findings and examine ways in which schools have elected or omitted to adopt certain strategies with the "opening" of racially exclusive schools in South Africa.

\section{Some conceptual clarifications}

\subsection{Reinventing and renegotiating the construct of "race"}

Interrogating the concept of race has been and still is a problematic transnational discourse (McCarthy et al., 2003; Winant, 2000; Nieto, 2000; McCarthy and Crichlow, 1993). During the early years of the 20th century, Du Bois and Boas proposed a revolutionary interpretation of race, debunking the traditional theory of race as an essential biological "truth" (Winant, 2000). Rather, race as an inconstant socio-historical construct dictated by economic variables, was proposed and is now a widely accepted view (McCarthy et al., 2003; [Dolby, 2000] and [Dolby, 2001]; Winant, 2000; Nieto, 2000; Carrim, 1998; McCarthy and Crichlow, 1993; Morrison, 1993). Hence, any study seeking to insert "race" as an analytic category in the social process needs to problematise race as socially, historically and ideologically constructed, rather than accept it as a biological or physical fact. As Roediger (2003) writes, "race" is constructed differently across time by people of the same social class, and differently at the same time by people whose class positions differ.

The mercurial nature of race and racial analysis is a discernible signifier of social interactions through which perceptions of whiteness and blackness are formulated; whiteness as the subject, blackness as the object or "the other" ([Dolby, 2000] and [Dolby, 2001]; Hall, 1996a; Morrison, 1993). Reliant on each other for their interpretations (McCarthy et al., 2003), whiteness and blackness are constantly shifting connotations of the political and social context in which they are situated (McCarthy et al., 2003; [Dolby, 2001] and [Dolby, 2002]; Morrison, 1993). However, the simplistic polarisation of these constructs has served to entrench views of homogeneity rather than dispel them, and in its wake has left race and racial experience being recast as static and essentialised (Hall, 1996a). These reductionist conceptions of race, casting whiteness as the norm against blackness, the subaltern, have, unofficially, sanctioned the continuation of racism ([Dolby, 2000] and [Dolby, 2001]; Nieto, 2000; Morrison, 1993). In consequence, with institutions such as schools reflecting this erratic social discourse, differential standards of societal power, privilege and positioning are consigned to whiteness (Delpit, 1988), relegating blackness to inconsequentiality:

... society categorizes people according to both visible and invisible traits, uses such classifications to deduce fixed behavioural and mental traits, and then applies policies and practices that benefit others. (Nieto, 2000:35)

The polarities of whiteness and blackness can further be embodied as first-and thirdworld constructs, respectively. However, the contestation between the first and third world, whiteness and blackness (Dolby, 2002), has been problematised by the advent of 
globalisation (McCarthy et al., 2003). With the accompanying escalation of cultural and human transborder migration, race has taken on a new identity (McCarthy et al., 2003).

Cultural identity can be approached in two ways (Hall, 1996b). One is the idea that oppressed groups can represent themselves and throw off negative representations from the colonial era through a recovery of the past. From this perspective, the past is viewed as an originary unity and idealised as the pre-conquest state to which the group would like to return. This is a kind of strategic essentialism. The other approach to identity is to avoid such essentialism by looking at identity as something that is produced. Identity is created from the ingredients of a personal past but is always in a process of transformation. It focuses on becoming rather than being and is formed in accordance with how one is positioned by and positions oneself with respect to the past. Identity is always influenced by culture, history and power.

The power of the first notion of identity and its strategic validity has been recognised (Hall, 1996b). However, according to Hall (1996c) such strategic essentialism would be replaced by "hybridity" as the archetypal post-modern experience. Culture, power and history are combined in the concept of hybridity to enable us to understand the present circumstances of the people. In this blurring of cultural and economic borders, race is constantly being reinvented and renegotiated through mediums such as popular culture (Dolby, 2000; Wasserman \& Jacobs, 2003).

\subsection{Approaches for thinking through different ways of conceptualising intercultural education}

Critical race theory (CRT) and post-colonial theory are explored in this study as valuable approaches for thinking through different ways of conceptualising intercultural education and the difficulties of changing the western-derived models of schools and universities which have become global.

CRT examines the complex relationship between and among race, racism and jurisprudence (Guinier, 1991; Delgado, 1995; Ladson-Billings and Tate, 1995; Cadwell, 1996; Tate, 1997). There are no "canonical set of doctrines or methodologies to which CRT scholars subscribe. However, these scholars are unified by two common intereststo understand how a 'regime of white supremacy and its subordination of people of colour have been created and maintained in [society]"' (Crenshaw et al., 1995:xiii) and to change the bond that exists between law and racial power. CRT argues that only by looking at the narratives of those who have been victimised by the legal system can we understand the "socially ingrained" and "systemic" forces at work in their oppression (Pizarro, 1999).

Since reality, as we understand it, is primarily a socially constructed entity, critical race theorists argue that we must acknowledge the multiplicity of realities that exist in order to better understand specific manifestations of the interactions of these realities (LadsonBillings and Tate, 1995). Central to CRT is the notion that the dominant mindset of society, the shared stereotypes, beliefs and understanding can only be challenged through 
telling stories. As Tate (1997, p. 235) explains, "The voice of the individual can provide insight into the political, structural and representational dimensions of the legal system, especially as they relate to the group case."

Post-colonial theory provides a framework that highlights an appreciation of the powerful effects that European and later North American global dominance through colonialism and imperialism had on education. "Postcolonial critique focuses on forces of oppression and coercive domination that operate in the contemporary world: the politics of anticolonialism and neo-colonialism, race, gender, nationalisms, class and ethnicities define its terrain" (Young, 2001, p. 11; Bhabha, 1994; [Hall, 1996a], [Hall, 1996b], [Hall, 1996c] and [Hall, 1996d]; Mongia, 1996; Barker et al., 1994). Post-colonial studies focus different ways of stating the problems in the dominant discourses in education, for example, related to power (Foucault, 1979). Cultural hegemonic European knowledge is criticised in an attempt to reintroduce and give value to knowledge represented from the non-European world (Said, 1978; Bhabha, 1994; Gandhi, 1998, [Spivak, 1995] and [Spivak, 2000]). Further, post-colonial studies seek to deconstruct the ongoing discourses; it points out the need to ask questions and to focus different ways of stating the problems in the dominant discourses in education. For example, do all the students have the possibilities to be presented with the same opportunities?

The term hybrid is an important concept in post-colonial theory referring to the integration (or mingling) of cultural signs and practices from the colonising and colonised cultures. The assimilation and adaptation of cultural practices, the cross-fertilisation of cultures, can be seen as positive, enriching and dynamic as well as oppressive. "Hybridity" is also a useful concept for helping to break down the false sense that colonised cultures - or colonising cultures for that matter-are monolithic or have essential, unchanging features (Lye, 1998).

Homi Bhabha (1994) recognises that racial and cultural purity do not exist and that all cultures are to some degree hybrid. He celebrates hybridity for its ability to take one beyond essential identities. As Moore-Gilbert (1997) pointed out, Bhabha believes that cultural differences are irreducible. On the other hand, he dislikes the notion of cultural diversity because it implies that cultures should be treated as separate entities. Cultural diversity also has an exotic flavour. Instead, hybridity conceived as a "Third Space of enunciation" (Bhabha, 1994, p. 37) is his ideal.

Post-colonialism has shown how cultural identities shift as people experience new languages, experiences and understanding (Gandhi, 1998). Different cultures interact in a third space in which boundaries and borders become porous in the contemporary world.

\section{Research methodology and context of study}

This research study aimed to capture the nature of interactions among Grade 8 students in desegregated South African schools, and to investigate Grade 8 students' perceptions of interactions and their feelings of a sense of belonging to the school. The study was both descriptive and exploratory in nature. 
Three secondary schools in the large city of Tshwane ${ }^{2}$ in the Gauteng province of South Africa provide the research sites for this study. For convenience, the schools will be referred to as Broadstream, Silversands and Ridgewood. These schools were selected to represent the larger group of similar urban public schools where rapid desegregation had been implemented during the 10 years prior to this study. The three schools were former white Model $\mathrm{C}$ schools $^{3}$ and were selected because they comprised of students that came from all four of the "old racial categorisations". In all three schools, the racial profile of the student body was approximately 50\% white students, $42 \%$ African students, $7 \%$ Indian students and $2 \%$ Coloured students. Although the above groupings were categorised according to the old racial categorisations of South Africa, we need to remember that none of these groups are totally homogenous. Within each of these categories there was the play of intra-white and intra-black dynamics. Given that I have argued that the categories of black and white are not fixed and binary categories, for the purposes of this paper, I will be using these terms in analysing and discussing the data to determine whether new identities across racial borders are beginning to emerge.

Information available suggested that the race profile of the teaching cadre had remained relatively unaltered. It was thus suspect that there would be considerable mismatches between the linguistic and cultural backgrounds of the teachers and a significant proportion of the students at each school. What was not clear was how desegregation at the level of classroom and school practices was manifesting itself. Of particular interest were interactions between students.

The table at the end of the article presents a summary of the school profiles (Table 1).

The data-gathering techniques that were used in this study included a mix of interviews, observation and field notes. Interviews were the main data-gathering technique used in this study and were "semi-structured" in nature.

Interviews were conducted with Grade 8 students to determine what their perceptions were about the way in which the process of desegregation was unfolding in the school. The rationale for selecting Grade 8 students was that these students were at the adolescent stage of their lives where the self-creation of one's identity, which is often triggered by biological changes associated with puberty, the maturation of cognitive abilities and changing societal expectations and the process of simultaneous reflection and observation is commonly experienced (Tatum, 1999). Criteria used in the selection of students were based on racial background and gender.

The researcher selected approximately 13 students across five Grade 8 classes from each school. A total of 39 students were interviewed. These interviews were conducted in 2004 over a period of 4 weeks. Questions comprised of five broad categories and were open-ended. The duration of interviews ranged between $1 \frac{1}{2}$ and 2 hours. All interviews were recorded.

Observations were conducted to coincide with the interview period. One researcher observed Grade 8 classes at each school on seven occasions over a period of 6 weeks. A 
total of 21 classroom observations were conducted. The observations focused mainly on teacher-student interactions but also gave attention to issues of teacher professionalism, teacher practices and management of the class (physical layout, seating arrangements, monitor duty, curriculum delivery). The observer made notes that formed the basis of the analysis and that highlighted issues that arose during the observation sessions, with students that were interviewed.

However, it must be noted that there are advantages and limitations of observations at a small number of schools. The advantages of such a technique is that it provides a lens into the "lived experiences" of classroom life over a period of time that allows for indepth study and creates the opportunity for patterns (if any) to emerge. The limitation is that the small number of schools' observations could be seen as instructive and illustrative, and not as representative of all schools.

To get a better feel of the schooling and learning environment, various field notes were made, based on informal observations of these schools. Informal conversations were conducted with some teachers. Attention was also given to the physical appearance of the school, which included observations of artifacts such as paintings, décor, photographs, portraits and school magazines.

Data gathered was coded according to themes generated during the study and from literature reviewed in the field. Data was reduced into three categories, each consisting of smaller sub-categories. The major categories formed were: the "white way" is the "one way"; student commitment versus institutional culture and shifting selves: the emergence of new self-identities. The selected quotations in the findings and analysis sections of this paper best exemplify each of the identified categories.

\section{Findings of this study}

Three major findings emanated from this study.

\subsection{The "white way" is the "one way"}

Contrary to legislation and the "spirit of reconciliation" and despite considerable changes in the racial composition of these schools, it does not appear that these schools have shown much flexibility in accommodating the multitude of cultures and worldviews that black students have bought along with them. Jay, an Indian male from Ridgewood, aptly sums up the general attitude: "Because like at school, there's like, you can say the whites, like only believe in like one way, like you do one thing like one way." As appears to be the trend in the vast majority of desegregated schools in South Africa, students are expected to adjust their outlooks and their identities, molding themselves to the cast of the dominant culture. Consequently, this study found that assimilation is still the dominant approach at schools (Carrim, 1998; Vally and Dalamba, 1999). Essentially, students are expected to act and behave "white". Students wanting to "fit in" are placed under tremendous pressure to confirm and be absorbed into the system. 
The institutionalised racism of these schools, which is so obviously attempting to maintain the status quo, is apparent in the composition of teachers. At Ridgewood, for instance, compared to a multitude of white teachers, there was one coloured, one African, and one Indian-a veritable reflection of the "rainbow nation"!

A problematic phenomenon that has been observed at desegregated schools with a predominantly white teaching staff is that teachers tend to "teach to" white students, and ignore black students in the class (Nieto, 2000). Aware that they are being ignored, the students are inclined to attempt to gain their teachers' attention by being disruptive and rebellious (Nieto, 2000).

Many black students at these schools were not proficient in the language of instruction. They were thus doubly disadvantaged, as they had to cope with processing abstract concepts through an unfamiliar language, as well as having to accomplish this without the support of their teachers. What also often tends to be the case is that the intelligence of these students is judged by their ability to express themselves in English. The result is what Robert Merton referred to as "the self-fulfilling prophecy", whereby students perform according to the expectations of their teacher (Nieto, 2000, p. 43). In accordance with this term, students view their own ability as lesser than their peers who are fluent in English, and as a result underperform.

\section{2. "We are equal and we care for one another" vs. "they say we are stupid": student commitment vs. institutional racism}

In spite of the seeming indifference of the majority of teachers in initiating the dismantling of racial divides, students appear to be instinctively working toward unification.

Most students expressed the fundamental necessity of confronting past injustices so as to tackle the present social inequities in order to "give us another point of view from where people come from" (Thabo, African male, Silversands), and achieve true national reconciliation. This finding significantly diverges from the Vally and Dalamba report's (1999) negative appraisal of student commitment and serves as an inspirational signifier of South Africa's future. It is quite extraordinary how students have, on their own accord, embarked on the process of deconstructing the artificial boundaries imposed by the formed myth of race as a given truth, and are striving toward integration. The finding of this research is a momentous step forward and can only be done justice through the testimonies of students:

Yes, because some people... must learn to understand that there is no difference between us, just color difference. So they must understand that we can be together. (Jason, white male, Ridgewood)

I just think that we should come to terms that we are equal and that we care for one another. (Sipho, African male, Silversands) 
[to] understand that we are not racist and you know, we can be friends. (Costa, white male, Silversands)

Teachers were not actively promoting integration and at one school in particular they were reinforcing boundaries. When we asked Sipho how the different races mixed in his class, he answered: "There are no whites and no Indians, just Africans." According to students there are two homogenous classes: one African and one virtually all white; the other classes are fairly evenly mixed. This unacceptable nuance of segregation is not only inconsistent with the moral obligation schools have in providing equitable education, but contravenes legislation. It emerged that the "white" class comprised the academic achievers, as Michelle, a white female from that class told us: "In my class this year we've only got like four African people, the rest are white and then there are two Indians. I' $m$ in the best Grade 8 class and the people in there are really clever." Conversely, Sipho told us that the students in his class are rebellious and are viewed by the teachers as failures. On probing as to how teachers responded to their rebellion, Sipho replied: "they don't like it, they say we are stupid." Taken aback by such a revelation, we went on to ask him how this made him feel. Sipho, casting a downward glance, replied: "[we] feel down ... like we're nothing."

\section{3. "I sound and talk like a black person": emergence of new self-identities}

There was the virtual absence of race in the students' "self-articulation" (Carrim, 2000) of their identities. On a positive note, this could be interpreted as the refusal of the youth of South Africa to conform to the racial categories of old that were fundamental instruments in the abuse of human rights. Yet, on a more realistic level, students are aware of the societal stigma attached to openly talking about race (Makhanya, 2004, p. 19). Natalie (white female, Broadstream) succinctly summed up the prevailing attitude: "I don't know, people feel uncomfortable talking about other races in front of that race."

In an attempt to discard the label of oppressor, many white students adopted a colourblind approach. As Candice (white female from Broadstream) insisted, "I never see colour."

Research has indicated that what has often been the consequence is that black students have had their sense of identity "whitened" in order to have a feeling of belonging. Essentially, borrowing Berger's (1980) term of "the male gaze", they have come to view themselves through the eyes of the hegemonic order; "the race gaze". A resulting factor of the "race gaze" is that students are torn between two seemingly contradictory identities. Mpkazi (African, female, Broadstream) highlighted this issue: "I'm not there with it [identity/culture] if you can understand. I'm just a bit different." She narrated an incident with another student who asked her: "why don't you speak with a kind of African accent like other African people?" Mpkazi mentioned how this comment had troubled her as, "she may mean that I'm not in touch with my roots. I'm not African enough. She might mean that I act too white or something." Straddling two worldviews has left Mpkazi interpreting her identity through the eyes of another, in turn becoming the other. 
What this study has come to show is that, unlike Mpkazi, many students across racial lines are beginning to question and reject this static and forged identity. Rather, within a country that now celebrates difference, there is an explicit move toward the reclamation of the self. It appears that some students are beginning to dabble in the construction of a personal identity, using the medium of universal popular cultures to express their shifting selves (Wasserman and Jacobs, 2003). Ironically, it is often these students who are labelled as dissenters for not conforming: "[teachers] don't like us because we don't do what we supposed to do... they don't understand me, because they don't know who I am. They think that I'm somebody who I'm not" (Lee-Anne, white female, Ridgewood). This student's non-conformist and laid-back attitude, inspired by Reggae, has been a causative factor in her being labelled rebellious by her teachers.

\section{Analysis and discussion of findings}

\subsection{The "white way" is the "one way"}

The assimilationist approach implemented by these schools not only attempts to alter a student's identity but also, by implication sends a subliminal message to the student that his/her culture is subaltern (Nieto, 2000). With identity and value systems being so intrinsically linked, this process contributes towards the strengthening of the life-chances of the protectorates of the hegemonic culture, by eroding away at the "devalued" student's self-esteem. The following comment by Mpkazi (African female from Broadstream) encapsulates this trend of identity denigration and the need to conform to the dominant culture, "It's kind of like you are wondering why and maybe it's because we are a bit slow in progressing into... like their level." The prevailing ethos of "whiteness" at Broadstream has not only caused Mpkazi to question her own worth as embedded in her "background", but has also made it quite clear to her, that in order for her to find her place in the school, she must be absorbed into the dominant culture: "progress[ed] into their level." The approach adopted by the school clearly illustrates the powerful effects that European dominance, through colonialism and imperialism, had on education. Perhaps the answer to Mpkazi's question rests in post-colonial theory in which cultural hegemonic European knowledge is criticised in an attempt to reintroduce and give value to knowledge represented from the non-European world (Said, 1978; Bhabha, 1994; Gandhi, 1998; [Spivak, 1995] and [Spivak, 2000]). It would seem that hybridity, conceived, as a "Third space of enunciation" had no place at these schools.

The implications of a basically white teaching staff cannot be underestimated. Filtering through from the white-macro-culture's belief of their supposed superiority is the polarised belief of black ineptitude (Jansen, 2004). This belief is played out in the allied micro-culture of the school, sending an unambiguous message to black students of not only the incompetence of black teachers, but by implication, their own.

Black students are unable to fully identify with their white teachers. Consequently, endeavouring to conform to the supposed norms that the teacher as an agent of the culture of power projects, the student's identity is further denied. As a result, this largely 
homogenous teaching fraternity serves to further entrench the process of assimilation and deprive students of their cultural and linguistic heritage.

The tendency to marginalise black students became particularly evident during interviews with students from Ridgewood. Interestingly, it was a white female student, Lee-Anne, who critically exposed the prevalence of this practice of racial inequity at her school: "Well some of the teachers are fine with different colours and the "differentness" of us, but others exclude them. They don't understand why black students are doing what they doing, or for what reason ...so black students get a bad reputation...they are in the class but teachers are always against them and don't pay any attention to them ... and black students just rebel against it." This narrative resonates well with some of the key principles of CRT, in that it not only brings to the fore that fact that racism is a prevalent facet of life in our society but also unmasks and exposes racism in its various permutations (Delgado, 1995). Critical race theorists would argue that for Lee-Anne social reality has been created only through the story she has narrated and that the social and experiential context of racial oppression is crucial for understanding racial dynamics (Ladson-Billings, 1999; Delgado, 1995; Matsuda et al., 1993; [Roediger, 1991] and [Roediger, 2003]).

Subtle permutations of racism were also evident in observations of the teaching practice of some teachers in the form of silencing of the academic voices of black students. This "de-voicing" of the students can also be seen as an attempt by white teachers to diminish the self-worth of black students. This is indicative of a masked form of institutional racism, which serves to restrict the access of non-whites to "power and privilege" (Sleeter, 1993). CRT argues that the voice of the individual can provide insight into the political, structural and representational dimensions of the legal system, especially as they relate to the group case. Opportunities need to be created so that discourses in education can focus on different ways of stating the problem especially as it relates to issues of power.

This silencing figuratively extends beyond the walls of the classroom and permeates the power structures that have been conferred to students. Power translates into a prefect body, which is a select group of students in Grade 12 who preside over other students, implementing the school rules. In a sense they are the foot soldiers whose role is to further enforce the ethos of the school. Their role is particularly influential as they also serve as the mouthpiece of and for students. Students are fully aware that their success at the school, that is the possibility of being selected as a prefect and having their voices heard, are intrinsically linked to and dependent on their association with the "ruling" culture (Delpit, 1988). Subsequently, the "whiteness" of a student's attitude is a significant factor in the selection of the prefects. In questioning why the school has never had an African head prefect, Mpkazi subliminally yields to the positioning as the less significant "other", as projected through the eyes of the authoritative voice of the school: "[I] think that there are more white prefects because we aren't really equal or something." Schools as microcosms of society need to acknowledge the multiplicity of realities that exist in order to better understand specific manifestations of the interactions of these realities. Delgado (1995) argues that race and the "experiential knowledge of people of 
colour" are critical to understanding society. Seen from a post-colonial lens, Mpkazi is attempting to state the problem in a different way and the school as an institution needs to take heed of this.

\section{2. "We are equal and we care for one another" vs. "they say we are stupid": student commitment vs. institutional racism}

The situation is far from ideal, yet 7 years after the publication of the Vally and Dalamba report (1999) there appears to be a distinctive move by students towards a synthesising of previous cultural and racial divides. A definite trend by students of taking the initiative, where the institution has not, to promote cross-cultural and racial relationships was observed. According to most students, on the whole, there appears to be noteworthy racial mixing in classrooms. As Emily (white female from Broadstream) affirms: "it's basically mixed but different people react in different ways. There are many that are totally mixed, there are a couple of groups though, about two groups in the class, this is the Afrikaner side and this is the African side, its just exactly like that, they talk to each other, there is no borders or anything really."

At all these schools, students for the most part, grouped together in cultural and racial pockets during breaks. Twelve years after apartheid has formally been abolished, it appears that racial divides are still a prevalent aspect of the psyche of South Africans (Moodley and Adam, 2004; Lund, 2004). Roxanne (white female, Silversands) reasoned: "[students interact with their race and cultural groups at break] because they have the same culture, the same way of thinking, I don't know, they feel secure in people who are like them". Yet, it was Nomsa's (black female, Broadstream) pragmatic remark which signified and accentuated the repercussions of this racial and cultural pocketing: "Some students do not like to mix with students of a different race but they don't tell you I'm not going to hang out with you because you black, they just move away from you...in time they are so far away that you are not going to talk to them anymore."

The effects of apartheid and the affect of the regime's propaganda have permeated every aspect of the South African psyche. Apartheid's objective went beyond the ideology of racial segregation; the myth of white intellectual supremacy was fabricated in an attempt to justify the immorality of this abuse of human rights. A damaging consequence of this has been the ingrained perception of the inferior intellectual aptitude of Africans (Lund, 2004). As Sipho's peers can testify, a decade of democracy has not seen the debunking of this myth in all strata of society. The educational legacies of imperialism live on strongly within us and within our institutions. For example, we continue to place boundaries around human groups by the idea of "culture", which, with its 19th century roots, carries within it the residues of beliefs about race and nation that so, benefited the Europeans ([Willinsky, 1998] and [Willinsky, 1999]).

Most people do not consider themselves racist, yet still believe in the discredited 18th century ideas that humans are biologically divided into "races" and that there is some inherent overlap between race and culture. "None of us lives untouched by colonisation, 
the extraordinary ordinariness of whiteness, the cultural constructions of Other, or as part of an insulated and isolated island mass" (Crowley, 1999).

Schools have implemented an additive form of multiculturalism, which merely glosses over the basic aspects of major religions and cultures represented in South Africa. Jane (white female, Broadstream) affirmed, "We never go onto lines that are religion based, cultural based, what has happened in the past, anything like that. We just stay on the syllabus really. You know there is nothing, no wondering or discussions or anything like that." There is a notable absence of the interrogation of power structures that underlie societal relations. Rather, the form of multiculturalism practiced appears to be an attempt to contain the multiplicity of worldviews and value systems and is divorced from the reality of societal influences.

Apart from the political transformation in South African schools over the past 12 years, there has also been a dramatic move towards self-expression amongst the students who have begun questioning that, which was previously accepted as truth. This reclamation of the individual voice has left many teachers, who were shaped by the apartheid system, struggling to adjust to the inquiring nature of the current students. Instead of facing the challenge of political, social and personal analysis, teachers have opted to maintain safe ground. However students, untainted by apartheid's ideology of insular acceptance, have voiced their frustration of having to accept the comfort zone of ignorance retained by their teachers. Realising the consequence of ignorance, students are thirsting for the confrontation of contentious issues that are obstacles to equity:

People need to know, they need to know what happened, they need to get some feelings out. You know have a discussion, not let it get to heated but actually have a good discussion about it. It would help. (David, white male, Ridgewood).

A post-colonial view of the school as it currently exists would see it as an outdated European institution in many ways, including the way in which it promotes a curriculum steeped in the ethnocentric assumption that the West is best when it comes to knowledge. There is recognition that the traditional school almost inevitably promotes and reinforces socio-economic inequity (Hickling-Hudson, 2003; Ladwig, 2000).

\section{3. "I sound and talk like a black person": emergence of new self-identities}

Catalysed by globalisation, personas of division that characterised the South African identity of 12 years ago, have given way to a hybridised identity (Wasserman and Jacobs, 2003). The emergence of new identities and cultural self-perceptions must be interpreted in the trans-global flow of cultural and economic capital (McCarthy et al., 2003). Emerging from decades of isolation from the international community, South Africa's current role as a player in the global village has resulted in psychological and cultural borders becoming ever more indistinct. Previously, defined boundaries have become blurred and the rigid racial categories of old are being subverted and replaced by fluid interpretations of what it means to be a South African (Wasserman and Jacobs, 2003). 
Jethro's articulation of his identity captures this inconstant hybridism: "I'm Coloured, I have Indian family, and I have a Hip Hop culture."

Research into popular culture in the South African schooling context has made known the conjunctive association of specific races with a particular form of popular culture (Dolby, 2000). It was shown that popular culture served to redefine notions of whiteness through fictional links with a conceptualised view of euro-centricity, or what Dolby refers to as "global whiteness" (Dolby, 2000). An aspect of this popular culture of global whiteness took the form of techno music (Dolby, 2000). Played against this new imaging of whiteness, was an abstract blackness, conveyed through the popular culture of hip-hop, rap and $R$ 'n'B.

However, what has emerged from this study is that a blurring of these illusory borders and synthesising of cultures is taking place on the school grounds. Jason (white male, Ridgewood) is emblematic of these re-articulated forms of identity. Intrigued by a white student using rap and hip-hop-style jargon, I asked Jason what style of music he likes and whether he felt that it is in any way representative of his identity: "Um, Hip Hop, Rap House music, R'n'B... people like get a style and a thing from music...yes, you could actually quite say that [that this music is representative of the way he perceives his identity]." I asked Jason whether he felt that his teachers have an understanding of who he is as a person. To this he rejoined "No, some of the teachers don't because I hang out with a lot of African people during break and so the teachers say, the White teacher $\mathrm{Mr} P$ says that I sound and talk like a black person, actually I don't care that's me who I am...if he doesn't like the way I talk then he must just leave me alone."

The term hybrid as used by post-colonialists refer to the integration or mingling of cultural signs and practices from the colonising and colonised cultures. Jason's and Jethro's stories tell of the assimilation and adaptation of cultural practices, the crossfertilisation of cultures, that they see as positive, enriching and dynamic. Lye (1998) argues that "hybridity" is a useful concept for helping to break down the false sense that cultures are monolithic or have essential, unchanging features.

Jason celebrates this hybridity because it affords him the opportunity to go beyond essential identities and to challenge the notion of stable identities. Instead, hybridity for Jason, allows him to dabble in a "Third Space of enunciation" (Bhabha, 1994, p. 37) in which boundaries and borders become porous in the contemporary world.

\section{Conclusion}

As a dominant global player, South Africa is no longer an isolated country resilient to trans-global changes. Consequently, globalisation and its cultural offshoot of popular culture are currently informing and influencing the ever-shifting identities of South Africa's youth. In this study, it emerged that young South Africans are subliminally rejecting racial categories of old. This emergence of new self-identities, refusing to be contained by prescriptions of the past, has seen students like Jason, Lee-Anne and Jethro becoming the synthesis, discarding homogeneous identities for an unfixed and inclusive 
"South African" identity. For these students, the formation of their identities is to a large extent shaped by the historical, political and social contexts in which they are currently located. They judge themselves in what they perceive to be the way in which others judge them. Hence, Jason's remark "the White teacher Mr P says that I sound and talk like a black person, actually I don't care that's me who I am...” And conversely for Sipho “... they say we are stupid... [We] feel down... like we're nothing."

A decade of democracy has witnessed students moving from overt racial practices as in derogatory name calling and stereotyping as identified in the Vally and Dalamba report (1999) to a situation of improved inter-cultural attitudes and less negative stereotyping, prejudice and discrimination in these schools. Processes of migration, diaspora formation and cultural hybridisation have transformed individual and group identities and created "new ethnicities". Rather than being fixed and essentialised, these new forms of cultural identity are contingent and fluid ([Hall, 1992] and [Hall, 1996d]; Hoogvelt, 1997). Although, as this study has uncovered, it may be only a few students at these schools, the potential for intercultural harmony cannot be undermined.

CRT and post-colonial theory offer considerable explanatory power for the racial separateness that have plagued our past and continue to compromise our hope for equitable education. For critical race theorists, "reality is socially constructed" and "stories are a powerful means for destroying and changing mind-sets" (Delgado, 1995). Post-colonial perspectives would have significant implications for challenging and changing the traditional culture of schools. Post-colonial teaching involves helping students to identify and critique the different "regimes of truth" that characterise our social arrangements, and to build positive identities that move easily between the local and the global.

CRT and post-colonial theory are extremely applicable to the South African education context. Central to these modes of thought is a concern to "re-narrativise" ([Hall, 1996a], [Hall, 1996b], [Hall, 1996c] and [Hall, 1996d]) the globalisation story in a way that places historically marginalised parts of the world at the centre, rather than at the periphery of the education and globalisation debate ([Tikly, 1999] and [Tikly, 2001]). South African education changes as viewed and analysed through the lens of these theories depicts a central concern with the continuing impact on education systems of European colonialism, and with issues of race, culture, language, as well as other forms of social stratification including class and gender in post-colonial contexts. A postcolonial critique draws attention to the transnational aspects of globalisation and of social inequalities and seeks to highlight forms of resistance to Western global hegemony as they have manifested themselves in education ([Tikly, 1999] and [Tikly, 2001]).

These theories are in alignment with the notion of the African renaissance that involves a struggle against Africa's marginalisation in economic and political terms as much as it involves a celebration and development of African cultures. Tikly (2003:561) claims, "the African Renaissance is an important concept because it represents an indigenous response to the challenges of globalisation." In this respect, it fits with the Gramscian notion of the formation of a post-colonial historical bloc. Education can play a crucial 
role in South Africa's renewal because of its central importance for economic, political and cultural development. In this respect, education is a sine qua non for the African renaissance.

Schools and other educational institutions are a significant locus where different cultural forms interact. Government has a key role to play in "levelling the playing fields" in terms of opportunities afforded to different groups. Negotiating issues of language, identity and power is critical in the South African context. It links directly with economic globalisation and is deeply implicated in the maintenance of support, and resistance to emerging hegemonic projects. In this regard, normative support from school authorities I believe would make the attainment of other optimal conditions far easier and help to accelerate this process.

Schools should promote democracy through maximising opportunities for dialogue. Schools require agreements on common values and these are reached through discussion. This requires that minority voices be given opportunities for expression and that conscious efforts are made to dismantle the barrier of racism, which inhibits participation. As expressed by Dewey ([1916] 2002, p. 97):

In order to have a large number of values in common, all the members of the group must have an equable opportunity to receive and to take from others.

Education for democratic citizenship is inconceivable without debate and discussion that is inclusive of many voices and perspectives. Indeed, debate and discussion require diversity. As Parker (2004, p. 453) notes: "diversity figures as the most central deliberative asset". Diversity, in other words is the essence of democracy.

Although this study has found that attitudes of schools and teachers have resisted change, it has become apparent that students are constructing new trans-racial and cultural identities and actively working towards a South Africa where, "the spirit of Ubuntu-that profound African sense that we are human only through the humanity of other human beings - is not a parochial phenomenon, but [adds] globally to our common search for a better world" (Cryws-Williams, 1997, p. 82).

The significance of this research in relation to international development issues and in a broader global context lies in the fact that most countries in the world face challenges of negotiating and mediating identity within a hybrid social context. This study provides a glimpse of how the youth are currently engaging with issues of race, identity, culture and ethnicity. Despite its concentration on the situation in South Africa, it has significance for the way in which education and life choices are conceived elsewhere in the world.

This study was exploratory in nature. A follow-up study aims to explore whether the patterns of white dominance described in this study are counterposed to patterns of Black self-effacement in all-African schools, or whether more assertive forms of identity are being cultivated. 


\section{References}

Barker, F., Hulme, P., Iversen, M., 1994. Introduction. In: F. Barker, P. Hulme and M. Iversen, Editors, Colonial Discourse/Postcolonial Theory, Manchester University Press, Manchester

Berger, J.1980. Ways of Seeing, Penguin Books Limited, Harmondsworth.

Bhabha, H.K. 1994. The Location of Culture, Routledge Books, London

Cadwell, V.F. 1996. Critical race theory: the key writings that formed the movement, Harvard Civil Rights-Civil Liberties Law Review 30 (5), pp. 1363-1374.

Carrim, N. 1998. Anti-racism and the 'New' South African educational order, Cambridge Journal of Education 28 (3), pp. 301-320.

Carrim, N. 2000. Critical anti-racism and problems in self-articulated forms of identities [1], Race Ethnicity and Education 3 (1), pp. 25-44.

Crowley, V. 1999. Towards a postcolonial curriculum for the new millennium. In: B. Johnson and A. Reid, Editors, Contesting the Curriculum, Social Science Press, Katoomba, NSW, pp. 100-111.

Crenshaw K.W., et al., 1995. Introduction. In: K. Crenshaw, N. Gotanda, G. Peller and K. Thomas, Editors, Critical Race Theory: The Key Writings that Formed the Movement, New Press, New York.

Cryws-Williams, J. (Ed.), 1997. In the Words of Nelson Mandela: A Little Pocketbook, Penguin Books, Parktown.

Delgado, R., 1995. Critical Race Theory: The Cutting Edge. Temple University Press, Philadelphia.

Delpit, L., 1988. Power and pedagogy in educating other people's children. The Harvard Educational Review 58, 280-298. Full-text

$</$ www.dkrc.org/bib/dkrc/paper/delpit88thesilenced.shtml>.

Dewey, J., [1916] 2002. Democracy and education: an introduction to the philosophy of education. In: Maxcy, S.J. (Ed.), John Dewey and American Education, vol. 3.

Thoemmes, Bristol.

Dolby, N., 2000. Changing selves: multicultural education and the challenge of new identities. Teachers College Record 102 (5), 898-911.

Full-text </http://search.epnet.com/direct.asp? an=3620524db=aph $>$. 
Dolby, N., 2001. White fright - the politics of white youth in South Africa. British Journal of Sociology of Education 22 (1), 5-17.

Full-text $<$ http://search.epnet.com/direct.asp?an=4273785\&db=aph $>$.

Dolby, N., 2002. Making white: constructing race in a South African high school. Curriculum Inquiry 32, 7-29.

Foucault, M., 1979. Discipline and Punish: The Birth of the Prison. Vintage, New York.

Gandhi, L., 1998. Postcolonial Theory: A Critical Introduction. Columbia, New York.

Guinier, L., 1991. No two seats: the elusive quest for political equality. Virginia Law Review 77, 1413-1514.

Hall, S., 1992. New ethnicities. In: Donald, J., Rattansi, A. (Eds.), 'Race', Culture and Difference. Sage, London.

Hall, S., 1996a. New ethnicities. In: Morley, D., Kuan-Hsing, C. (Eds.), Stuart Hall:

Critical Dialogues in Cultural Studies. Routledge, London.

Hall, S., 1996b. What is 'black' in black popular culture? In: Morley, D., Kuan-Hsing, C. (Eds.), Stuart Hall: Critical Dialogues in Cultural Studies. Routledge, London.

Hall, S., 1996c. Cultural identity and diaspora. In: Mongia, P. (Ed.), Contemporary Postcolonial Theory: A Reader. Arnold, London.

Hall, S., 1996d. 'When was the post-colonial'? thinking at the limit. In: Chamber, I., Curtis, L. (Eds.), The Post-colonial Question: Common Skies, Divided Horizons. Routledge, London.

Hoogvelt, A., 1997. Globalisation and the Postcolonial World: The New Political Economy of Development. Macmillan, Basingstoke.

Hickling-Hudson, A., 2003. Multicultural education and the postcolonial turn. Policy Futures in Education 1 (2), 381-401.

Jansen, J., 2004. Race, education and democracy after ten years-how far have we come? Prepared for the Institute for Democracy in South Africa (IDASA), Lessons from the Field: A Decade of Democracy in South Africa.

Ladson-Billings, G., 1999. Just what is critical race theory, andwhat's it doing in a nice field like education? In: Parker, L., Deyhle, D., Villenas, S.A. (Eds.), Race isyRace isn't: Critical Race Theory and Qualitative Studies in Education. Westview Press, Boulder, CO. 
Ladson-Billings, G., Tate, W.F., 1995. Toward a critical race theory of education. Teachers College Record 97 (1), 47-68.

Ladwig, J., 2000. World institutions, world dispositions: curriculum in the world cultural institution of schooling. In: Mahalingam, R., McCarthy, C. (Eds.), Multicultural Curriculum: New directions for Social Theory, Practice and Policy. Routledge, New York.

Lund, T., 2004. Colour blind. Fairlady, 22-26.

Lye, J., 1998. Some issues in postcolonial theory. Contemporary Literary Theory, Brock University. <http://www.brocku.ca/ english/courses/470/postcol.html>.

Makhanya, M., 2004. Whites must come on board. Sunday Times 19.

Matsuda, M.J., Lawrence, C.R., Delgado, R., Crenshaw, K.W. (Eds.), 1993. Words that Wound: Critical Race Theory, Assaultive Speech, and the First Amendment. Westview Press, Boulder, CO.

McCarthy, C., Crichlow, W., 1993. Introduction. In: McCarthy, C., Crichlow, W. (Eds.), Race Identity and Representation in Education. Routledge, New York.

McCarthy, C., Giardina, M.D., Harewood, S.J., Park, J., 2003. Contesting culture: identity and curriculum dilemmas in the age of globalization, postcolonialism, and multiplicity. Harvard Educational Review 73, 449-465.

Moletsane, R., Hemson, C., Muthukrishna, A., 2004. Educating South African teachers for the challenge of school integration: towards a teaching and research agenda. In: Nkomo, M., McKinney, C., Chisholm, L. (Eds.), Reflections on School Integration: Colloquium Proceedings. HSRC Publishers, Cape Town.

Mongia, P., 1996. Introduction. In: Mongia, P. (Ed.), Contemporary Postcolonial Theory: A Reader. Arnold, London.

Moodley, K.A., Adam, H., 2004. Citizenship education and political literacy in South Africa. In: Banks, J. (Ed.), Diversity and Citizenship Education: Global Perspectives. Jossey-Bass, San Francisco, CA.

Moore-Gilbert, B. 1997. HYPERLINK

$<$ http://www.amazon.com/exec/obidos/ISBN=1859840345/interculturalrel>. Postcolonial theory: Contexts, practices, politics. Verso, New York.

Morrison, T., 1993. Playing in the Dark-Whiteness and the Literary Imagination. Picador, London. 
Nieto, S., 2000. Affirming Diversity: The Sociopolitical Context of Multicultural Education, third ed. Addison Wesley Longman Inc.

Parker, 2004. Diversity, globalization and democratic education: curriculum possibilities. In: Banks, J. (Ed.), Diversity and Citizenship Education: Global Perspectives. JosseyBass, San Francisco, CA.

Pizarro, M., 1999. "Adelante!": toward social justice and empowerment. Chicana/o communities and Chicana/o studies. In: Parker, L., Deyhle, D., Villenas, S. (Eds.), Race is... race isn't: Critical Race Theory And Qualitative Studies in education. Westview, Boulder, CO, pp. 53-81.

Potgieter, C., 2002. Black Academics on the Move. Centre for Higher Education Transformation, Pretoria.

Roediger, D., 1991. The Wages of Whiteness: Race and the Makings of the American Working Class. Verso Press, London.

Roediger, D., 2003. Colored white: transcending the racial past. Journal of Sociology and Social Welfare.

Said, E., 1978. Orientialism. Random House, New York.

Sayed, Y., 2001. Post-apartheid educational transformation: policy concerns and approaches. In: Sayed, Y., Jansen, J. (Eds.), Implementing Education Policies. The South African Experience UCT Press, Cape Town.

Sleeter, C., 1993. How white teachers construct race. In: McCarthy, C., Crichlow, W. (Eds.), Race Identity and Representation in Education. Routledge, New York and London.

Soudien, C., 1994. Equality and equity in South Africa: multicultural education and change. Equity \& Excellence 27 (3), 55-60.

Soudien, C., Carrim, N., Sayed, Y., 2004. School inclusion and exclusion in South Africa: some theoretical and methodological considerations. In: Nkomo, M., McKinney, C., Chisholm, L. (Eds.), Reflections on School Integration.

Spivak, G.C., 1995. Can the subaltern speak. In: Aschroft, B., et al. (Eds.), The Postcolonial Studies Reader. Routledge, London.

Spivak, G.C., 2000. Upon reading the companion to postcolonial studies. In: Schwarz, Sangeeta Ray (Eds.), I: A Companion to Postcolonial Studies. Blackwell Publishers, Oxford. 
Tate IV, W.F., 1997. Critical race theory in education: history, theory and implications. In: Apple, M.W. (Ed.), Review of Research in Education, Vol. 22. American Educational Research Association, Washington, DC, pp. 195-250.

Tatum, B.D., 1999. “Why are all the Black Kids Sitting Together in the Cafeteria?', And other Conversations About Race. Basic Books University Press, USA.

Tikly, L., 1999. Post-colonialism and comparative education. International Review of Education 45 (5/6), 603-621.

Tikly, L., 2001. Globalisation and education in the post-colonial world: towards a conceptual framework. Comparative Education 37 (2), 151-171

Tikly, L., 2003. The African Renaissance, NEPAD and skills formation: an identification of key policy tensions. International Journal of Educational Development 23, 543-564.

Vally, S., Dalamba, Y., 1999. Racism, 'racial integration' and desegregation in South African public secondary schools: a report on a study by the South African Human Rights Commission (SAHRC), Johannesburg, SAHRC.

Wasserman, H., Jacobs, S., 2003. Introduction. In: Wasserman, H., Jacobs, S. (Eds.), Shifting Selves: Post-Apartheid Essays on Mass Media, Culture and Identity. Kwela Books, Cape Town.

Willinsky, J., 1998. Learning to Divide the World: Education at Empire's End. Willinsky, 1999. Curriculum, after culture, race, nation. Discourse: Studies in the Cultural Politics of Education 20 (1), 89-112.

Winant, H., 2000. The theoretical status of the concept of race. In: Back, L., Solomos, J. (Eds.), Theories of Race and Racism-A Reader. Routledge, London.

Young, R., 2001. Postcolonialism: An Historical Introduction. Blackwell, Oxford.

\section{Notes:}

${ }^{1}$ The terms Coloured, White, Indian and African derive from the apartheid racial classifications of the different peoples of South Africa. The use of these terms, although problematic, has continued through the post-apartheid era in the country. In our paper, we use these terms grudgingly to help present the necessary context for our work.

${ }^{2}$ Formerly known as Pretoria.

${ }^{3}$ Model C school: A government attempt to cut state costs by shifting some of the financing and control of White schools to parents. 
${ }^{4}$ Rainbow nation: Reflective of the diverse racial, cultural and language groups of people in South Africa. Limited English Proficiency - the learner comes from a home in which a language other than English is primarily used for communication and who has difficulty in understanding, speaking, reading or writing the English language. 
Table 1.

Profile of schools

\begin{tabular}{|c|c|c|c|}
\hline School name & Broadwater & Silverstream & Riverwood \\
\hline Type of school & $\begin{array}{l}\text { Ex-Model Ca, well- } \\
\text { resourced school }\end{array}$ & Ex-Model C & Ex-Model C \\
\hline Location & $\begin{array}{l}\text { Middle- to upper class } \\
\text { predominantly white } \\
\text { suburb }\end{array}$ & $\begin{array}{l}\text { Middle- to upper class } \\
\text { predominantly white } \\
\text { suburb }\end{array}$ & $\begin{array}{l}\text { Middle-class white } \\
\text { suburb. }\end{array}$ \\
\hline $\begin{array}{l}\text { Medium of } \\
\text { instruction }\end{array}$ & English & English & English \\
\hline Established & 1902 & Early 1976 & 1963 \\
\hline $\begin{array}{l}\text { Pre-1994- } \\
\text { Catered } \\
\text { exclusively to: }\end{array}$ & $\begin{array}{l}\text { White English-speaking } \\
\text { students }\end{array}$ & $\begin{array}{l}\text { White Afrikaans- } \\
\text { speaking }^{\text {b }} \text { students. }\end{array}$ & $\begin{array}{l}\text { White students, the } \\
\text { majority of whom } \\
\text { spoke English }\end{array}$ \\
\hline $\begin{array}{l}\text { Post } 1994- \\
\text { Student } \\
\text { population }\end{array}$ & $\begin{array}{l}1375 \text { (55\% white, } 34 \% \\
\text { African, } 8 \% \text { Indian and } \\
3 \% \text { Coloured) }\end{array}$ & $\begin{array}{l}970(55 \% \text { African, } 33 \% \\
\text { white, } 7 \% \text { Indian and } \\
5 \% \text { Coloured) }\end{array}$ & $\begin{array}{l}1080 \text { (41\% African, } \\
42 \% \text { white, } 12 \% \\
\text { Indian and } 5 \% \\
\text { Coloured) }\end{array}$ \\
\hline $\begin{array}{l}\text { Total number of } \\
\text { Grade } 8 \\
\text { students }\end{array}$ & 280 & 227 & 252 \\
\hline Teachers & $\begin{array}{l}81\left(73 \text { white }\left[37 \mathrm{GDE}^{\mathrm{c}} \text {; }\right.\right. \\
36 \mathrm{SGB}^{\mathrm{d}} \text { ]; } 4 \text { African [2 } \\
\text { GDE; } 2 \text { SGB]; } 3 \text { Indian } \\
\text { SGB; } 1 \text { Coloured SGB }\end{array}$ & $\begin{array}{l}46 \text { (37 white [24 GDE; } \\
13 \text { SGB]; } 2 \text { Indian SGB, } \\
2 \text { Coloured GDE and } 5 \\
\text { African [ } 3 \text { GDE; } 2 \\
\text { SGB] }\end{array}$ & $\begin{array}{l}59 \text { (56 white [32 } \\
\text { GDE; } 24 \text { SGB], } 1 \\
\text { Indian SGB, } 1 \\
\text { Coloured SGB and } 1 \\
\text { African SGB }\end{array}$ \\
\hline $\begin{array}{l}\text { Teacher- } \\
\text { student ratio }\end{array}$ & $1: 28$ & $1: 28$ & $1: 25$ \\
\hline School fees & R $8300-00$ & R 7020-00 & R 6250-00 \\
\hline $\begin{array}{l}\text { Mode of } \\
\text { transportation }\end{array}$ & Privately owned cars & Taxis & $\begin{array}{l}\text { "Bussing-in"e } \\
\text { phenomenon }\end{array}$ \\
\hline
\end{tabular}


${ }^{\text {a }}$ Model C school (a government attempt to cut state costs by shifting some of the financing and control of white schools to parents.

${ }^{b}$ Afrikaans is one of the eleven official languages recognized by South Africa s new constitution. In the previous dispensation, only English and Afrikaans were recognized as official languages and languages of instruction in whites-only schools.

${ }^{\mathrm{c}}$ GDE-Gauteng Department of Education (Provincial Department of Education).

Gauteng is one of the nine provinces of South Africa. It is the richest province in the country and includes such cities as Johannesburg and the administrative capital city of Pretoria.

${ }^{\mathrm{d}}$ SGB-School Governing Body.

${ }^{\mathrm{e}}$ Bussing- in-a phenomenon that has occurred post 1994, where large numbers of African students are transported by bus from neighbouring Black suburbs to middle class English medium schools. 